ORNL/TM-2019/1315

Revision 0

\title{
Determination of Average Burnup in AGR-2 Compacts 3-3-1, 3-3-2, 2-2-2, and 6-4-2
}

John D. Hunn

Fred C. Montgomery

Tamara J. Keever Benjamin D. Roach

Ralph H. llgner

September 2019 


\title{
DOCUMENT AVAILABILITY
}

Reports produced after January 1, 1996, are generally available free via US Department of Energy (DOE) SciTech Connect.

Website www.osti.gov

Reports produced before January 1, 1996, may be purchased by members of the public from the following source:

\author{
National Technical Information Service \\ 5285 Port Royal Road \\ Springfield, VA 22161 \\ Telephone 703-605-6000 (1-800-553-6847) \\ TDD 703-487-4639 \\ Fax 703-605-6900 \\ E-mailinfo@ntis.gov \\ Website http://classic.ntis.gov/
}

Reports are available to DOE employees, DOE contractors, Energy Technology Data Exchange representatives, and International Nuclear Information System representatives from the following source:

Office of Scientific and Technical Information

PO Box 62

Oak Ridge, TN 37831

Telephone 865-576-8401

Fax 865-576-5728

E-mail reports@osti.gov

Website http://www.osti.gov/contact.html

This report was prepared as an account of work sponsored by an agency of the United States Government. Neither the United States Government nor any agency thereof, nor any of their employees, makes any warranty, express or implied, or assumes any legal liability or responsibility for the accuracy, completeness, or usefulness of any information, apparatus, product, or process disclosed, or represents that its use would not infringe privately owned rights. Reference herein to any specific commercial product, process, or service by trade name, trademark, manufacturer, or otherwise, does not necessarily constitute or imply its endorsement, recommendation, or favoring by the United States Government or any agency thereof. The views and opinions of authors expressed herein do not necessarily state or reflect those of the United States Government or any agency thereof. 


\title{
DETERMINATION OF AVERAGE BURNUP IN \\ AGR-2 COMPACTS 3-3-1, 3-3-2, 2-2-2, AND 6-4-2
}

\author{
John D. Hunn \\ Fred C. Montgomery \\ Tamara J. Keever \\ Benjamin D. Roach \\ Ralph H. Ilgner
}

Revision 0

Date Published: September 2019

\author{
Work sponsored by \\ US DEPARTMENT OF ENERGY \\ Office of Nuclear Energy - Advanced Reactor Technologies \\ under the
}

Advanced Gas Reactor Fuel Development and Qualification Program

Prepared by

OAK RIDGE NATIONAL LABORATORY

Oak Ridge, TN 37831-6283

managed by

UT-BATTELLE, LLC

for the

US DEPARTMENT OF ENERGY

under contract DE-AC05-00OR22725 



\section{CONTENTS}

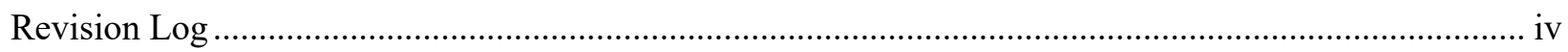

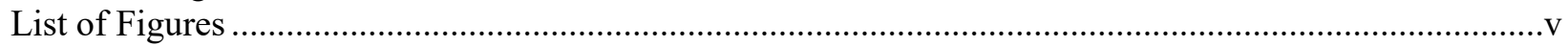

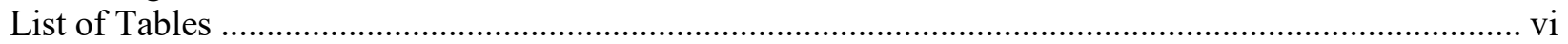

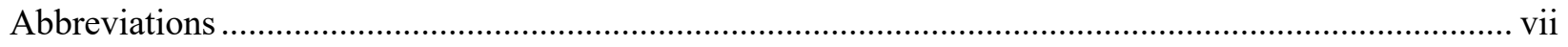

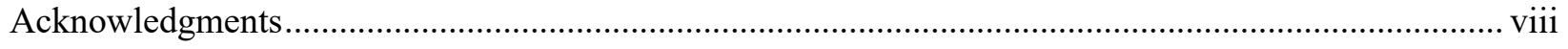

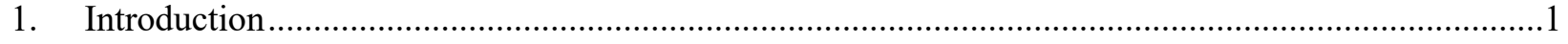

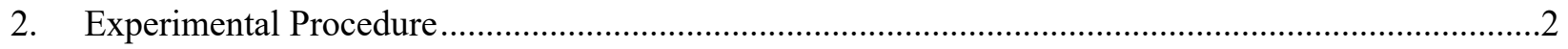

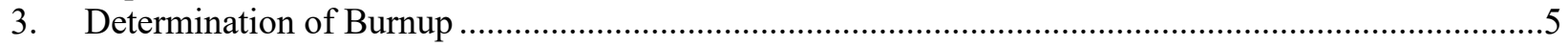

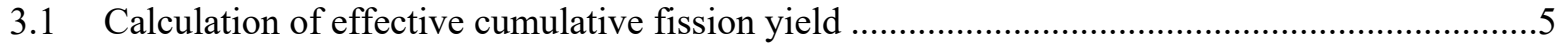

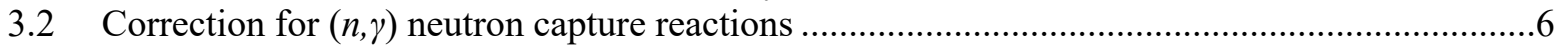

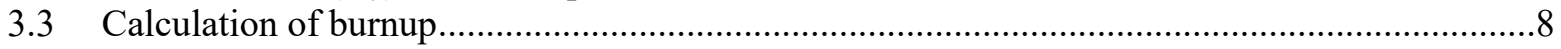

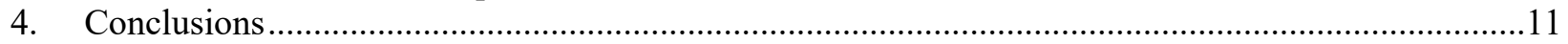

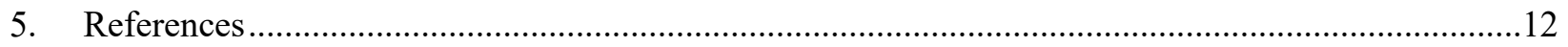




\section{REVISION LOG}

\begin{tabular}{llll}
\hline Revision & Date & Affected Pages & Revision Description \\
\hline 0 & & All & Initial issue
\end{tabular}




\section{LIST OF FIGURES}

2-1. Images used to count particle samples from Compact 3-3-1 (arbitrary scaling) ................................

2-2. Images used to count particle samples from Compact 3-3-2 (arbitrary scaling)................................ 


\section{LIST OF TABLES}

1-1. Average irradiation conditions for AGR-2 compacts subjected to burnup analysis ............................1

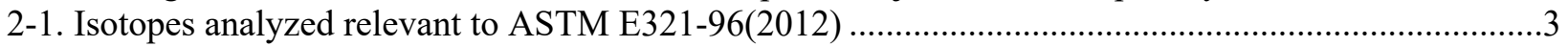

2-2. Elution profile script for the elemental separation of neodymium from all isobaric interferences ........4

3-1. Calculation of effective cumulative fission yield for ${ }^{148} \mathrm{Nd}$ in AGR-2 Compact 3-3-1 ........................

3-2. Calculation of effective cumulative fission yield for ${ }^{148} \mathrm{Nd}$ in AGR-2 Compact 3-3-2 ...........................5

3-3. Calculation of effective cumulative fission yield for ${ }^{148} \mathrm{Nd}$ in AGR-2 Compact 2-2-2 ........................6

3-4. Calculation of effective cumulative fission yield for ${ }^{148} \mathrm{Nd}$ in AGR-2 Compact 6-4-2 .....................6

3-5. Summary of effective cumulative fission yields for the stable and long-lived neodymium isotopes ....6

3-6. Correction factors for $(\mathrm{n}, \gamma)$ neutron capture reactions

3-7. Correction factors used for ${ }^{147} \mathrm{Nd}(\mathrm{n}, \gamma)^{148} \mathrm{Nd}$ neutron capture reaction in ORNL/TM-2018/931 ............7

3-8. Burnup based on fission production of ${ }^{\mathrm{Z}} \mathrm{Nd}$ in Compact 3-3-1 and Compact 3-3-2 ........................8

3-9. Burnup based on fission production of ${ }^{\mathrm{Z}} \mathrm{Nd}$ in Compact 2-2-2 and Compact 6-4-2 …...................9

3-10. Average calculated moles of ${ }^{142} \mathrm{Nd}$ compared with measured moles of ${ }^{142} \mathrm{Nd}$................................

3-11. Burnup from measured ${ }^{148} \mathrm{Nd}$ using different neutron capture reaction correction factors ................10

4-1. Summary of burnup analyses and comparison with JMOCUP calculations .....................................11 


\section{ABBREVIATIONS}

AGR Advanced Gas Reactor (Fuel Development and Qualification Program)

AGR-2 second AGR program irradiation experiment

FIMA fissions per initial metal atom

$\mathrm{HCl}$ hydrochloric acid

HPIC high-pressure-ion-chromatography

IFEL Irradiated Fuels Examination Laboratory

IMGA Irradiated Microsphere Gamma Analyzer

JMOCUP Jim Sterbentz's MCNP-ORIGEN2 coupled utility program

MCNP Monte Carlo N-Particle Transport code

NACIL Nuclear Analytical Chemistry \& Isotopics Laboratory

ORIGEN Oak Ridge Isotope Generation and Depletion code

ORNL Oak Ridge National Laboratory

PIE post-irradiation examination

$\mathrm{TA}_{\max } \quad$ time-average maximum (temperature)

$\mathrm{TA}_{\min } \quad$ time-average minimum (temperature)

TAVA time-average, volume-average (temperature)

TRISO tristructural-isotropic (coated particles)

UCO uranium carbide/uranium oxide mixture (fuel kernels)

$\mathrm{UO}_{2} \quad$ uranium dioxide (fuel kernels)

$\mathrm{Z} \quad$ atomic number 


\section{ACKNOWLEDGMENTS}

This work was sponsored by the US Department of Energy's Office of Nuclear Energy-Advanced Reactor Technologies as part of the Advanced Gas Reactor Fuel Development and Qualification Program. Hot cell activities were supported by the staff of the Oak Ridge National Laboratory Irradiated Fuels Examination Laboratory. Analysis of leach solutions was provided by the Oak Ridge National Laboratory Nuclear Analytical Chemistry \& Isotopics Laboratory.

A special thank you goes to Dr. James W. Sterbentz of Idaho National Laboratory, who extracted the information from the AGR-2 daily depletion simulation data (Sterbentz 2014) that was needed to refine the burnup calculations. Namely, that information was the correction factors that were used to adjust the measured concentrations of each stable neodymium isotope ${ }^{\mathrm{Z}} \mathrm{Nd}$ for the ${ }^{\mathrm{Z}-1} \mathrm{Nd}(\mathrm{n}, \gamma)^{\mathrm{Z}} \mathrm{Nd}$ and ${ }^{\mathrm{Z}} \mathrm{Nd}(\mathrm{n}, \gamma)^{\mathrm{Z}+1} \mathrm{Nd}$ reactions that occurred throughout the irradiation, and the fractions the relevant heavy metal isotopes contributed to the total number of fissions that were used to estimate the effective cumulative fission yield for ${ }^{\mathrm{Z}} \mathrm{Nd}$. 


\section{INTRODUCTION}

Burnup measurements have been performed on irradiated tristructural-isotropic (TRISO) particle fuel compacts from the Advanced Gas Reactor (AGR) Fuel Development and Qualification Program's second irradiation experiment (AGR-2). The AGR-2 irradiation experiment used TRISO particles fabricated by BWX Technologies (Barnes and Marshall 2009) and formed into compacts in the Oak Ridge National Laboratory (ORNL) Coated Particle Fuel Development Laboratory. Two compact lots were fabricated that differed in kernel type. The compact lot designated by LEU09-OP2-Z contained kernels made up of uranium carbide and uranium oxide (UCO) that were nominally $425 \mu \mathrm{m}$ in diameter and $14 \%$ enriched (Hunn, Montgomery, and Pappano 2010a). The compact lot designated by LEU11-OP2-Z contained kernels made of only uranium dioxide $\left(\mathrm{UO}_{2}\right)$ that were nominally $500 \mu \mathrm{m}$ in diameter and $9.6 \%$ enriched (Hunn, Montgomery, and Pappano 2010b). The addition of carbide to the kernel provides a getter for excess oxygen generated by the fission of $\mathrm{UO}_{2}$. This gettering reduces the formation of carbon monoxide, which allows TRISO particles to go to higher burnup and temperature with significantly reduced probability for failure of the silicon carbide layer (Morris et al. 2016).

Average burnup measurements have been completed on random samples of particles from four AGR-2 compacts for comparison with the average burnup values that were estimated via physics depletion calculations using the Oak Ridge Isotope Generation and Depletion (ORIGEN2) code (Croff 1983; Ludwig and Croff 2002), the Monte Carlo N-Particle Transport (MCNP) code (X-5 Monte Carlo Team 2003), and Jim Sterbentz's MCNP-ORIGEN2 coupled utility program (JMOCUP) and software extraction modules (Sterbentz 2014). Table 1-1 lists these four compacts with information on the estimated average burnup in percent fissions per initial metal atom (FIMA), the fast neutron fluence (neutron energies $>0.18 \mathrm{MeV}$ ), and the compact temperatures during irradiation in terms of the timeaverage, volume-average (TAVA), time-average minimum $\left(\mathrm{TA}_{\max }\right)$, and time-average maximum $\left(\mathrm{TA}_{\max }\right)$. Burnup measurement results for AGR-2 UCO Compact 2-2-2 and AGR-2 UCO Compact 6-4-2 are reported in ORNL/TM-2018/931 (Montgomery et al. 2018). Reported herein are the results of additional refinement of the burnup calculation for these two UCO compacts and new results obtained from the analysis of particles from AGR-2 $\mathrm{UO}_{2}$ Compact 3-3-1 and AGR-2 $\mathrm{UO}_{2}$ Compact 3-3-2.

Table 1-1. Average irradiation conditions for AGR-2 compacts subjected to burnup analysis

\begin{tabular}{|c|c|c|c|c|c|c|c|}
\hline \multirow{2}{*}{$\begin{array}{l}\text { AGR-2 } \\
\text { compact }^{a}\end{array}$} & \multirow{2}{*}{$\begin{array}{l}\text { Kernel } \\
\text { type }\end{array}$} & \multirow{2}{*}{$\begin{array}{l}\text { Fabrication } \\
\text { identification }^{b}\end{array}$} & \multirow{2}{*}{$\begin{array}{l}\text { Estimated } \\
\text { burnup }^{c}\end{array}$} & \multirow{2}{*}{$\begin{array}{l}\text { Fast fluence }{ }^{c} \\
(\mathrm{E}>0.18 \mathrm{MeV})\end{array}$} & \multicolumn{3}{|c|}{ Irradiation temperature $^{d}$} \\
\hline & & & & & TAVA & $\mathrm{TA}_{\min }$ & $\mathrm{TA}_{\max }$ \\
\hline $3-3-1$ & $\mathrm{UO}_{2}$ & LEU11-OP2-Z106 & $10.46 \%$ FIMA & $3.49 \times 10^{25} \mathrm{n} / \mathrm{m}^{2}$ & $1,062^{\circ} \mathrm{C}$ & $997^{\circ} \mathrm{C}$ & $1,104^{\circ} \mathrm{C}$ \\
\hline $3-3-2^{e}$ & $\mathrm{UO}_{2}$ & LEU11-OP2-Z034 & $10.54 \%$ FIMA & $3.53 \times 10^{25} \mathrm{n} / \mathrm{m}^{2}$ & $1,062^{\circ} \mathrm{C}$ & $999^{\circ} \mathrm{C}$ & $1,105^{\circ} \mathrm{C}$ \\
\hline $2-2-2^{e}$ & $\mathrm{UCO}$ & LEU09-OP2-Z075 & $12.55 \%$ FIMA & $3.39 \times 10^{25} \mathrm{n} / \mathrm{m}^{2}$ & $1,287^{\circ} \mathrm{C}$ & $1,189^{\circ} \mathrm{C}$ & $1,354^{\circ} \mathrm{C}$ \\
\hline $6-4-2^{e}$ & $\mathrm{UCO}$ & LEU09-OP2-Z049 & $9.26 \%$ FIMA & $2.21 \times 10^{25} \mathrm{n} / \mathrm{m}^{2}$ & $1,018^{\circ} \mathrm{C}$ & $894^{\circ} \mathrm{C}$ & $1,106^{\circ} \mathrm{C}$ \\
\hline
\end{tabular}

${ }^{a}$ The X-Y-Z compact numbering convention denotes the compact's location in the irradiation test train: capsule-level-stack.

${ }^{b}$ Physical properties data are available and referenced by fabrication identification number for individual UCO compacts (Hunn, Montgomery, and Pappano 2010a, 60-69) and individual $\mathrm{UO}_{2}$ compacts (Hunn, Montgomery, and Pappano 2010b, 73-82).

${ }^{c}$ Burnup (Sterbentz 2014, Table 6) and fast fluence (Sterbentz 2014, Table 12) are based on physics calculations.

${ }^{d}$ TAVA temperature, $\mathrm{TA}_{\min }$ temperature, and $\mathrm{TA}_{\max }$ temperature are based on thermal calculations (Hawkes 2014, Table 3).

${ }^{e}$ Compact was previously safety tested at $1,600^{\circ} \mathrm{C}$. 


\section{EXPERIMENTAL PROCEDURE}

The AGR-2 compacts were irradiated at the Idaho National Laboratory Advanced Test Reactor (Collin 2014). After irradiation, select compacts were subjected to the standard suite of post-irradiation examination (PIE) described in detail in (Hunn et al. 2013). This PIE included the following steps that generated the particle archives from which samples were riffled for burnup analysis. Each compact was electrolytically deconsolidated to free the TRISO particles from the surrounding matrix, and the particles and matrix debris were leached in hot nitric acid. After leaching, the particles were separated from the matrix debris with a sieve and were surveyed with the ORNL Irradiated Microsphere Gamma Analyzer (IMGA). If the IMGA survey identified any particles with low cesium or cerium inventory, they were selectively removed from the compact population for further analysis. The other particles were recomposited and riffled with a chute splitter to randomly separate out $\sim 10 \%$ as a TRISO particle archive. The remaining $\sim 90 \%$ of the compact population was subjected to particle burn-leach analysis (matrix debris was subjected to a separate matrix burn-leach analysis). The particle burn-leach analysis included heating the particles in air at $750^{\circ} \mathrm{C}$, which removed the outer pyrolytic carbon layer, as well as any other exposed carbon. After the burn, particles were leached again in hot nitric acid. After the final acid leach, particles were rinsed with water, dried, and collected as a particle burn-leach archive.

Particles were riffled from the particle burn-leach archive with a chute splitter to randomly separate out particles for burnup analysis. For each compact subjected to burnup analysis, the fraction of particles that were selectively removed based on the IMGA survey was less than $0.5 \%$ of the compact population. Therefore, the removal of these particles did not significantly impact the random sampling of the particles used for burnup analysis. Burnup analysis has been completed on the two 150-particle samples from Compact 3-3-1, shown in Figure 2-1, and the two 150-particle samples from Compact 3-3-2, shown in Figure 2-2. There were 199-200 particles in each sample taken from Compact 2-2-2 and Compact 6-4-2 for burnup analysis (Montgomery et al. 2018). The number of particles in the burnup samples from the $\mathrm{UO}_{2}$ compacts was lower than the number in the burnup samples from the UCO compacts because of the higher radioactivity in the larger $\mathrm{UO}_{2}$ kernels.

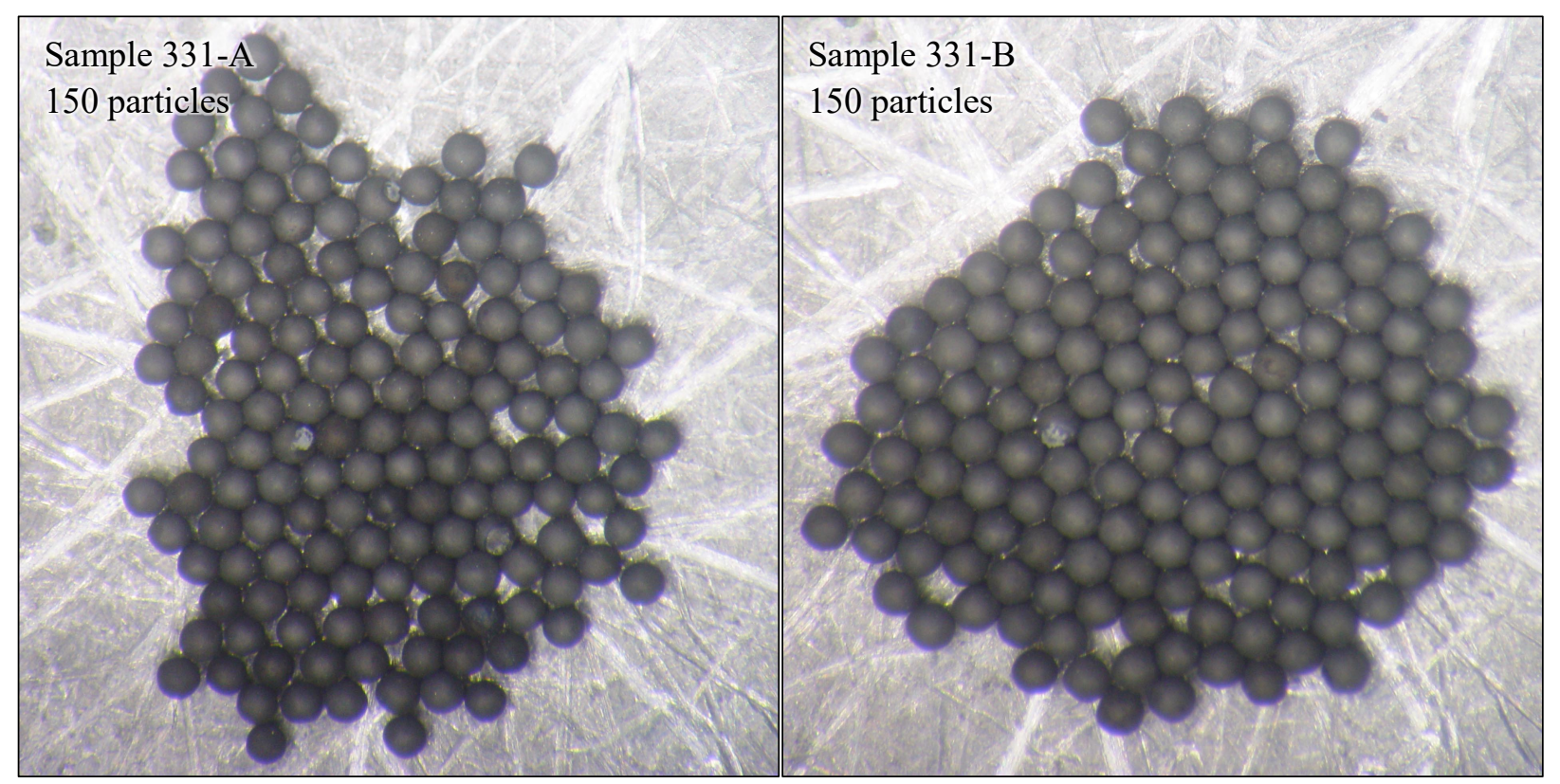

Figure 2-1. Images used to count particle samples from Compact 3-3-1 (arbitrary scaling). 


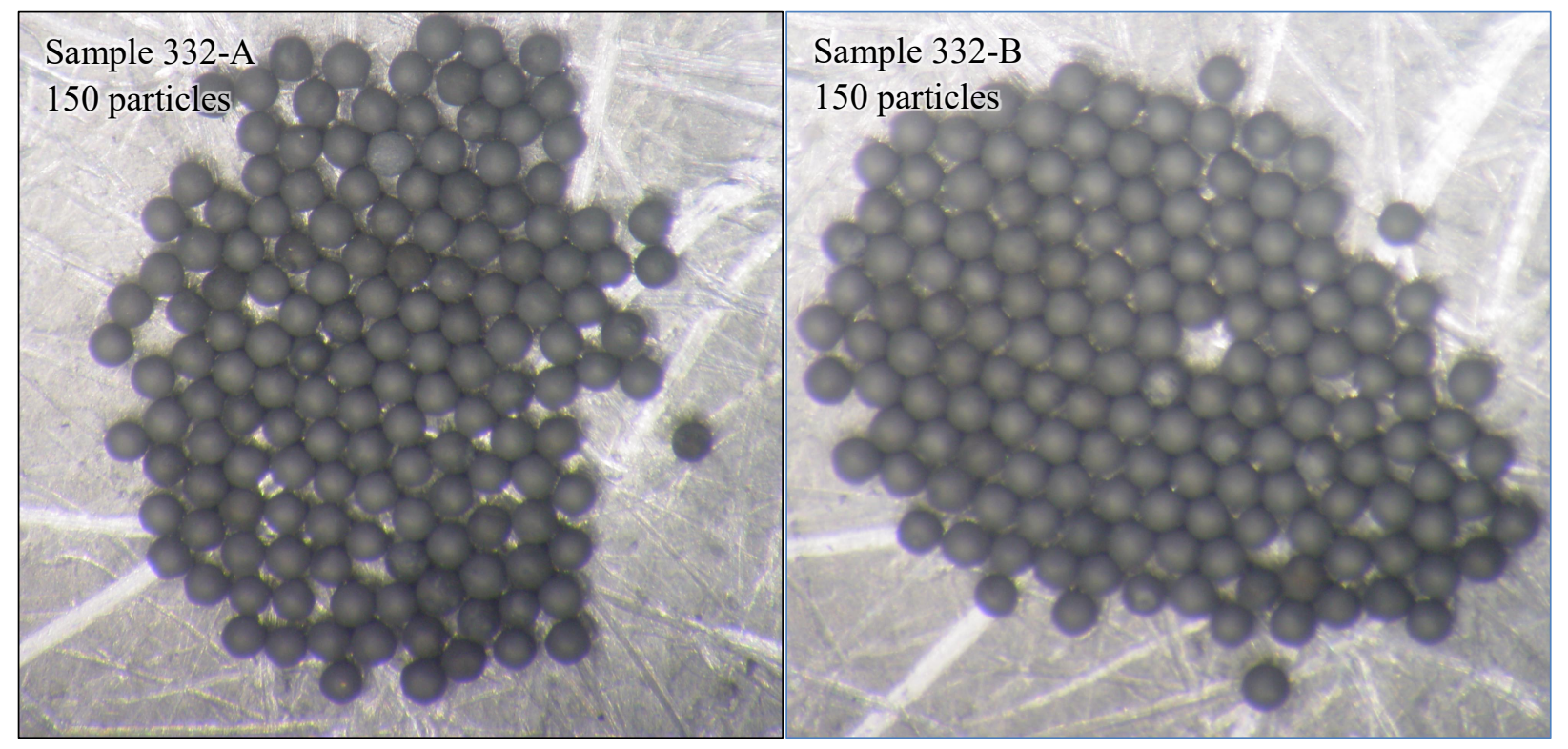

Figure 2-2. Images used to count particle samples from Compact 3-3-2 (arbitrary scaling).

Details of the equipment and procedures used in the Irradiated Fuels Examination Laboratory (IFEL) to produce solutions for burnup analysis are available in Section 2 of ORNL/TM-2018/931 (Montgomery et al. 2018) and are described only briefly herein. Each particle sample was sealed in a low-density polyethylene bottle and pulverized in a SPEX ${ }^{\mathrm{TM}}$ SamplePrep $8000 \mathrm{M}$ mill to expose the kernels. After pulverization was complete, the sealed polyethylene bottle was placed inside a quartz Soxhlet thimble, and the loaded thimble was placed into a quartz flask. The bottle and its contents were burned in air by slowly ramping from room temperature to $750^{\circ} \mathrm{C}$ and holding at $750^{\circ} \mathrm{C}$ for $8 \mathrm{~h}$. This burn process reduced the bottle and carbon in the coating debris to residual ash and converted most of the kernel material to a more acid-soluble oxide form. Dissolution of the oxidized residue was accomplished with nitric acid and a Soxhlet extractor. After weighing the solutions from the first and second extractions, $30-50 \mathrm{~mL}$ aliquots were taken for transfer from the IFEL to the Nuclear Analytical Chemistry \& Isotopics Laboratory (NACIL) for chemistry analysis to determine the amount of each of the isotopes of uranium, plutonium, and neodymium listed in Table 2-1.

Table 2-1. Isotopes analyzed relevant to ASTM E321-96(2012)

\begin{tabular}{ll}
\hline Element & Analyzed isotopes \\
\hline Uranium & $233,234,235,236,238$ \\
Plutonium & $238,239,240,241,242$ \\
Neodymium & $142,143,144,145,146,148,150$ \\
\hline
\end{tabular}

The analyses performed in the NACIL are described in Section 3 of ORNL/TM-2018/931 (Montgomery et al. 2018). The high-pressure-ion-chromatography (HPIC) elution profile used to isolate neodymium in the Compact 2-2-2 and Compact 6-4-2 analyses (Montgomery et al. 2018, Table 5) was changed for the Compact 3-3-1 and Compact 3-3-2 analyses to that shown in Table 2-2. An increase in the diglycolic acid concentration accelerated the neodymium elution, which occurred at $\sim 600 \mathrm{~s}$ after the start of the HPIC elution process using $0.1 \mathrm{M}$ diglycolic acid vs. $\sim 750 \mathrm{~s}$ after the start of the process using $0.006 \mathrm{M}$ diglycolic acid (Montgomery et al. 2018, Figure 8). A hydrochloric acid ( $\mathrm{HCl}$ ) wash using Fisher Scientific Optima high-purity $2 \mathrm{M} \mathrm{HCl}(<1 \mathrm{ppt} \mathrm{Nd})$ and a final water rinse were added to the end of the elution profile to aid in removal of excess uranium left in the separation column. This modification did not affect the elution of neodymium, which was complete before the $\mathrm{HCl}$ rinse segment began. 
Table 2-2. Elution profile script for the elemental separation of neodymium from all isobaric interferences

\begin{tabular}{lcccccc}
\hline $\begin{array}{l}\text { Segment } \\
\text { type }\end{array}$ & $\begin{array}{c}\text { Segment } \\
\text { duration }\end{array}$ & $\begin{array}{c}\text { Segment } \\
\text { end time }\end{array}$ & $\begin{array}{c}\text { Deionized } \\
\text { water }\end{array}$ & 2 M hydrochloric acid & 0.1 M diglycolic acid & 0.15 M oxalic acid \\
\hline Start & $0 \mathrm{~s}$ & $0 \mathrm{~s}$ & $100 \%$ & $0 \%$ & $0 \%$ & $0 \%$ \\
Ramp & $300 \mathrm{~s}$ & $300 \mathrm{~s}$ & $40 \%$ & $0 \%$ & $0 \%$ & $60 \%$ \\
Hold & $240 \mathrm{~s}$ & $540 \mathrm{~s}$ & $40 \%$ & $0 \%$ & $0 \%$ & $60 \%$ \\
Ramp & $0 \mathrm{~s}$ & $540 \mathrm{~s}$ & $20 \%$ & $0 \%$ & $0 \%$ & $80 \%$ \\
Ramp & $540 \mathrm{~s}$ & $1080 \mathrm{~s}$ & $51 \%$ & $0 \%$ & $23 \%$ & $26 \%$ \\
Ramp & $120 \mathrm{~s}$ & $1200 \mathrm{~s}$ & $0 \%$ & $0 \%$ & $100 \%$ & $0 \%$ \\
Hold & $300 \mathrm{~s}$ & $1500 \mathrm{~s}$ & $0 \%$ & $0 \%$ & $100 \%$ & $0 \%$ \\
Ramp & $0 \mathrm{~s}$ & $1500 \mathrm{~s}$ & $0 \%$ & $100 \%$ & $0 \%$ & $0 \%$ \\
Hold & $120 \mathrm{~s}$ & $1620 \mathrm{~s}$ & $0 \%$ & $100 \%$ & $0 \%$ & $0 \%$ \\
Ramp & $120 \mathrm{~s}$ & $1740 \mathrm{~s}$ & $100 \%$ & $0 \%$ & $0 \%$ & $0 \%$ \\
Hold & $60 \mathrm{~s}$ & $1800 \mathrm{~s}$ & $100 \%$ & $0 \%$ & $0 \%$ & $0 \%$ \\
\hline
\end{tabular}

Note: The listed eluent fractions are the target fractions at the end of each segment. Changes in eluent fractions during a ramp segment were made at a constant rate so that the fractions would reach the target fractions at the end of the segment. Eluent fractions were constant during each hold segment.

Note: Total flow rate for each step was $1 \mathrm{~mL} / \mathrm{min}$. 


\section{DETERMINATION OF BURNUP}

In ORNL/TM-2018/931, Montgomery et al. (2018) described a method based on ASTM E321-96 (2012) that was used to calculate average burnup for AGR-2 Compact 2-2-2 and Compact 6-4-2. Equation 1 is the basic equation in ASTM E321-96 (2012) used to determine the burnup in \%FIMA, $F_{T}$, where $F^{\prime}$ is the number of atoms in the fuel that underwent fission and $U^{\prime}$ and $P u^{\prime}$ are the atoms of uranium and plutonium remaining after irradiation.

$$
F_{T}=\left[F^{\prime} /\left(U^{\prime}+P u^{\prime}+F^{\prime}\right)\right] \times 100 .
$$

The ASTM E321-96 (2012) method relies on the measurement of ${ }^{148} \mathrm{Nd}$ to determine the number of fissioned atoms via Equation 2, where $F Y_{E}\left({ }^{148} N d\right)$ is the effective cumulative fission yield of ${ }^{148} \mathrm{Nd}$.

$$
F^{\prime}=\left({ }^{148} N d \text { atoms from fission }\right) / F Y_{E}\left({ }^{148} N d\right) .
$$

\subsection{CALCULATION OF EFFECTIVE CUMULATIVE FISSION YIELD}

In the AGR-2 irradiation, the dominant contributors to fission production of ${ }^{\mathrm{Z}} \mathrm{Nd}$ for atomic number $(\mathrm{Z})$ of $143,144,145,146,148$, and 150 were three thermal neutron fission processes $\left({ }^{235} U_{t h}{ }^{239} P u_{t h}\right.$, and $\left.{ }^{241} \mathrm{P} u_{t h}\right)$ and one fast neutron fission process $\left({ }^{238} U_{\text {fast }}\right)$. The value of $F Y_{E}\left({ }^{Z} N d\right)$ can be estimated as the weighted sum of the cumulative fission yields, $F Y\left({ }^{Z} N d\right)$, from these four dominant fission processes. Table 3-1 and Table 3-2 show the values used to estimate $F Y_{E}\left({ }^{148} N d\right)$ in AGR-2 $\mathrm{UO}_{2}$ Compact 3-3-1 and Compact 3-3-2, respectively. Ignoring the other fission processes introduced a systematic error in $F Y_{E}\left({ }^{148} \mathrm{Nd}\right)$ of less than $0.0009 \%$. The estimated fraction each fission process contributed to the total number of fissions was based on the fraction each related heavy metal isotope contributed to the total number of fissions. Table 3-3 and Table 3-4 show similar information for AGR-2 UCO Compact 2-2-2 and Compact 6-4-2, respectively.

\begin{tabular}{|c|c|c|c|c|}
\hline Fission process & $F Y\left({ }^{148} N d\right)^{a}$ & Weighting factor ${ }^{b}$ & $F Y_{E}\left({ }^{148} N d\right)$ contribution & Total $F Y_{E}\left({ }^{148} N d\right)$ \\
\hline${ }^{235} U_{t h}$ & $1.674 \% \pm 0.006 \%$ & $69.424 \% \pm 0.694 \%$ & $1.1618 \% \pm 0.0123 \%$ & \\
\hline${ }^{238} U_{\text {fast }}$ & $2.113 \% \pm 0.015 \%$ & $0.508 \% \pm 0.005 \%$ & $0.0107 \% \pm 0.0001 \%$ & \\
\hline${ }^{239} P u_{t h}$ & $1.642 \% \pm 0.008 \%$ & $25.545 \% \pm 0.255 \%$ & $0.4195 \% \pm 0.0047 \%$ & $1.679 \% \pm 0.013 \%$ \\
\hline${ }^{241} P u_{t h}$ & $1.932 \% \pm 0.014 \%$ & $4.476 \% \pm 0.045 \%$ & $0.0865 \% \pm 0.0011 \%$ & \\
\hline Other & $<2.000 \%$ & $0.0470 \% \pm 0.0003 \%$ & $<0.0009 \%$ & \\
\hline
\end{tabular}

Table 3-1. Calculation of effective cumulative fission yield for ${ }^{148} \mathrm{Nd}$ in AGR-2 Compact 3-3-1

${ }^{a}$ Cumulative fission yields from ENDF/B-VII.1 (Chadwick et al. 2011) were downloaded from www.nndc.bnl.gov.

${ }^{b}$ The percentage each heavy metal isotope contributed to the total number of fissions was based on data extracted from the AGR-2 daily depletion simulation (Sterbentz 2014). An uncertainty of $1 \%$ was assumed for the weighting factor for each fission process.

Table 3-2. Calculation of effective cumulative fission yield for ${ }^{148} \mathrm{Nd}$ in AGR-2 Compact 3-3-2

\begin{tabular}{lcrcc}
\hline Fission process & $F Y\left({ }^{148} N d\right)^{a}$ & Weighting factor ${ }^{b}$ & $F Y_{E}\left({ }^{148} N d\right)$ contribution & Total $F Y_{E}\left({ }^{148} N d\right)$ \\
\hline${ }^{235} U_{\text {th }}$ & $1.674 \% \pm 0.006 \%$ & $69.139 \% \pm 0.691 \%$ & $1.1571 \% \pm 0.0123 \%$ & \\
${ }^{238} U_{\text {fast }}$ & $2.113 \% \pm 0.015 \%$ & $0.511 \% \pm 0.005 \%$ & $0.0108 \% \pm 0.0001 \%$ & \\
${ }^{239} P u_{t h}$ & $1.642 \% \pm 0.008 \%$ & $25.750 \% \pm 0.258 \%$ & $0.4228 \% \pm 0.0047 \%$ & $1.679 \% \pm 0.013 \%$ \\
${ }^{241} P u_{t h}$ & $1.932 \% \pm 0.014 \%$ & $4.552 \% \pm 0.046 \%$ & $0.0879 \% \pm 0.0011 \%$ & \\
Other & $<2.000 \%$ & $0.0473 \% \pm 0.0003 \%$ & $<0.0009 \%$ & \\
\hline
\end{tabular}

${ }^{a}$ Cumulative fission yields from ENDF/B-VII.1 (Chadwick et al. 2011) were downloaded from www.nndc.bnl.gov.

${ }^{b}$ The percentage each heavy metal isotope contributed to the total number of fissions was based on data extracted from the AGR-2 daily depletion simulation (Sterbentz 2014). An uncertainty of $1 \%$ was assumed for the weighting factor for each fission process. 
Table 3-3. Calculation of effective cumulative fission yield for ${ }^{148} \mathrm{Nd}$ in AGR-2 Compact 2-2-2

\begin{tabular}{|c|c|c|c|c|}
\hline Fission process & $F Y\left({ }^{148} N d\right)^{a}$ & Weighting factor ${ }^{b}$ & $F Y_{E}\left({ }^{148} \mathrm{Nd}\right)$ contribution & Total $F Y_{E}\left({ }^{148} N d\right)$ \\
\hline${ }^{235} U_{t h}$ & $1.674 \% \pm 0.006 \%$ & $79.677 \% \pm 0.797 \%$ & $1.3334 \% \pm 0.0141 \%$ & \\
\hline${ }^{238} U_{\text {fast }}$ & $2.113 \% \pm 0.015 \%$ & $0.404 \% \pm 0.004 \%$ & $0.0085 \% \pm 0.0001 \%$ & \\
\hline${ }^{239} P u_{t h}$ & $1.642 \% \pm 0.008 \%$ & $17.219 \% \pm 0.172 \%$ & $0.2827 \% \pm 0.0032 \%$ & $1.676 \% \pm 0.014 \%$ \\
\hline${ }^{241} P u_{t h}$ & $1.932 \% \pm 0.014 \%$ & $2.657 \% \pm 0.027 \%$ & $0.0513 \% \pm 0.0006 \%$ & \\
\hline Other & $<2.000 \%$ & $0.0428 \% \pm 0.0003 \%$ & $<0.0009 \%$ & \\
\hline
\end{tabular}

${ }^{a}$ Cumulative fission yields from ENDF/B-VII.1 (Chadwick et al. 2011) were downloaded from www.nndc.bnl.gov.

${ }^{b}$ The percentage each heavy metal isotope contributed to the total number of fissions was based on data extracted from the AGR-2 daily depletion simulation (Sterbentz 2014). An uncertainty of $1 \%$ was assumed for the weighting factor for each fission process.

Table 3-4. Calculation of effective cumulative fission yield for ${ }^{148} \mathrm{Nd}$ in AGR-2 Compact 6-4-2

\begin{tabular}{|c|c|c|c|c|}
\hline Fission process & $F Y\left({ }^{148} N d\right)^{a}$ & Weighting factor ${ }^{b}$ & $F Y_{E}\left({ }^{148} \mathrm{Nd}\right)$ contribution & Total $F Y_{E}\left({ }^{148} N d\right)$ \\
\hline${ }^{235} U_{t h}$ & $1.674 \% \pm 0.006 \%$ & $85.923 \% \pm 0.859 \%$ & $1.4380 \% \pm 0.0152 \%$ & \\
\hline${ }^{238} U_{\text {fast }}$ & $2.113 \% \pm 0.015 \%$ & $0.363 \% \pm 0.004 \%$ & $0.0077 \% \pm 0.0001 \%$ & \\
\hline${ }^{239} \mathrm{P} u_{t h}$ & $1.642 \% \pm 0.008 \%$ & $12.690 \% \pm 0.127 \%$ & $0.2084 \% \pm 0.0023 \%$ & $1.673 \% \pm 0.015 \%$ \\
\hline${ }^{241} P u_{t h}$ & $1.932 \% \pm 0.014 \%$ & $0.996 \% \pm 0.010 \%$ & $0.0192 \% \pm 0.0002 \%$ & \\
\hline Other & $<2.000 \%$ & $0.0276 \% \pm 0.0002 \%$ & $<0.0006 \%$ & \\
\hline
\end{tabular}

${ }^{a}$ Cumulative fission yields from ENDF/B-VII.1 (Chadwick et al. 2011) were downloaded from www.nndc.bnl.gov.

${ }^{b}$ The percentage each heavy metal isotope contributed to the total number of fissions was based on data extracted from the AGR-2 daily depletion simulation (Sterbentz 2014). An uncertainty of $1 \%$ was assumed for the weighting factor for each fission process.

Table 3-5 is a summary of the estimated effective cumulative fission yields for all the relevant stable and long-lived neodymium isotopes that were measured for use in the burnup calculations. These were calculated in the same manner as described for the $F Y\left({ }^{148} \mathrm{Nd}\right)$ values presented in Table 3-1-Table 3-4.

Table 3-5. Summary of effective cumulative fission yields for the stable and long-lived neodymium isotopes

\begin{tabular}{lcccc}
\hline Isotope & AGR-2 Compact 3-3-1 & AGR-2 Compact 3-3-2 & AGR-2 Compact 2-2-2 & AGR-2 Compact 6-4-2 \\
\hline$F Y\left({ }^{143} N d\right)$ & $5.490 \% \pm 0.046 \%$ & $5.486 \% \pm 0.046 \%$ & $5.646 \% \pm 0.051 \%$ & $5.740 \% \pm 0.055 \%$ \\
$F Y\left({ }^{144} \mathrm{Nd}\right)$ & $4.986 \% \pm 0.042 \%$ & $4.981 \% \pm 0.042 \%$ & $5.157 \% \pm 0.047 \%$ & $5.259 \% \pm 0.050 \%$ \\
$F Y\left({ }^{145} \mathrm{Nd}\right)$ & $3.659 \% \pm 0.030 \%$ & $3.656 \% \pm 0.030 \%$ & $3.750 \% \pm 0.034 \%$ & $3.805 \% \pm 0.036 \%$ \\
$F Y\left({ }^{146} \mathrm{Nd}\right)$ & $2.850 \% \pm 0.023 \%$ & $2.849 \% \pm 0.023 \%$ & $2.899 \% \pm 0.026 \%$ & $2.927 \% \pm 0.027 \%$ \\
$F Y\left({ }^{148} \mathrm{Nd}\right)$ & $1.679 \% \pm 0.013 \%$ & $1.679 \% \pm 0.013 \%$ & $1.676 \% \pm 0.014 \%$ & $1.673 \% \pm 0.015 \%$ \\
$F Y\left({ }^{150} \mathrm{Nd}\right)$ & $0.761 \% \pm 0.006 \%$ & $0.762 \% \pm 0.006 \%$ & $0.724 \% \pm 0.006 \%$ & $0.701 \% \pm 0.006 \%$ \\
\hline
\end{tabular}

Note: There are no significant cumulative fission yields for ${ }^{142} \mathrm{Nd}$.

Note: The cumulative fission yields used to calculate the effective cumulative fission yields provided in this table came from ENDF/B-VII.1 (Chadwick et al. 2011) and were downloaded from www.nndc.bnl.gov.

Note: An uncertainty of $1 \%$ was assumed for the weighting factor for each fission process.

\subsection{CORRECTION FOR $(n, \gamma)$ NEUTRON CAPTURE REACTIONS}

Two corrections are recommended in ASTM E321-96 (2012) to determine the number of ${ }^{148} \mathrm{Nd}$ atoms from fission used in Equation 2 from the number of ${ }^{148} \mathrm{Nd}$ atoms measured in the sample. One is to account for the presence of natural neodymium based on the measured value of ${ }^{142} \mathrm{Nd}$, and the other is to account for the production of ${ }^{148} \mathrm{Nd}$ by the ${ }^{147} \mathrm{Nd}(\mathrm{n}, \gamma){ }^{148} \mathrm{Nd}$ neutron capture reaction. These corrections were applied in ORNL/TM-2018/931 to determine the number of ${ }^{148} \mathrm{Nd}$ atoms from fission in the particle samples from Compact 2-2-2 and Compact 6-4-2 (Montgomery et al. 2018). Because the table of factors to correct for the ${ }^{147} \mathrm{Nd}(\mathrm{n}, \gamma){ }^{148} \mathrm{Nd}$ neutron capture reaction based on the neutron flux and fluence provided 
in ASTM E321-96 (2012) did not cover the irradiation conditions for Compact 2-2-2 and Compact 6-4-2, an ${ }^{147} \mathrm{Nd}(\mathrm{n}, \gamma)^{148} \mathrm{Nd}$ correction factor was estimated from Figure 3 in a paper by Suyama and Mochizuki (2005). It was recommended in ORNL/TM-2018/931 that a more direct estimation of the correction factor could be obtained by extracting information on the fraction of each isotope that was formed and lost during the AGR-2 irradiation test from the daily depletion simulation. It was also recommended that data for the other neodymium isotopes should be considered for burnup determination to take advantage of the availability and accuracy of these measured values obtained as a result of the online direct-injection isotope-dilution high-pressure-ion-chromatography inductively coupled plasma mass spectrometry technique used to measure ${ }^{148} \mathrm{Nd}$.

For the calculations presented herein, corrections to the measured concentration of each stable neodymium isotope ${ }^{\mathrm{Z}} \mathrm{Nd}$ for the ${ }^{\mathrm{Z}-1} \mathrm{Nd}(\mathrm{n}, \gamma)^{\mathrm{Z}} \mathrm{Nd}$ and ${ }^{\mathrm{Z}} \mathrm{Nd}(\mathrm{n}, \gamma)^{\mathrm{Z}+1} \mathrm{Nd}$ reactions that occurred throughout the irradiation were extracted by J. W. Sterbentz from the AGR-2 daily depletion simulation data (Sterbentz 2014). Table 3-6 lists the correction factors for the four AGR-2 compacts subjected to burnup analysis.

Table 3-6. Correction factors for $(n, \gamma)$ neutron capture reactions

\begin{tabular}{lcccc}
\hline Isotope & AGR-2 Compact 3-3-1 & AGR-2 Compact 3-3-2 & AGR-2 Compact 2-2-2 & AGR-2 Compact 6-4-2 \\
\hline${ }^{142} \mathrm{Nd}$ & $1.0193 \pm 0.0102$ & $1.0193 \pm 0.0102$ & $1.0158 \pm 0.0102$ & $1.0093 \pm 0.0101$ \\
${ }^{143} \mathrm{Nd}$ & $1.8037 \pm 0.0180$ & $1.8127 \pm 0.0181$ & $1.6564 \pm 0.0166$ & $1.3295 \pm 0.0133$ \\
${ }^{144} \mathrm{Nd}$ & $0.6114 \pm 0.0061$ & $0.6098 \pm 0.0061$ & $0.6354 \pm 0.0064$ & $0.7280 \pm 0.0073$ \\
${ }^{145} \mathrm{Nd}$ & $1.1523 \pm 0.0115$ & $1.1535 \pm 0.0115$ & $1.1305 \pm 0.0113$ & $1.0743 \pm 0.0107$ \\
${ }^{146} \mathrm{Nd}$ & $0.8691 \pm 0.0087$ & $0.8683 \pm 0.0087$ & $0.8833 \pm 0.0088$ & $0.9268 \pm 0.0093$ \\
${ }^{148} \mathrm{Nd}$ & $0.9714 \pm 0.0097$ & $0.9708 \pm 0.0097$ & $0.9746 \pm 0.0097$ & $0.9847 \pm 0.0098$ \\
${ }^{150} \mathrm{Nd}$ & $1.0064 \pm 0.0101$ & $1.0065 \pm 0.0101$ & $1.0055 \pm 0.0101$ & $1.0034 \pm 0.0100$ \\
\hline
\end{tabular}

Note: An uncertainty of $1 \%$ was assumed for the correction factors.

Table 3-7 is a reproduction of Table 7 from ORNL/TM-2018/931 (Montgomery et al. 2018). The correction factors for the ${ }^{148} \mathrm{Nd}$ from ${ }^{147} \mathrm{Nd}(\mathrm{n}, \gamma){ }^{148} \mathrm{Nd}$ reaction given in Table 3-7 are slightly lower than the corresponding correction factors in Table 3-6 that were determined using the AGR-2 daily depletion simulation data. The Table 3-7 values do not include the ${ }^{146} \mathrm{Nd}(\mathrm{n}, \gamma){ }^{147} \mathrm{Nd}$ and ${ }^{148} \mathrm{Nd}(\mathrm{n}, \gamma){ }^{149} \mathrm{Nd}$ reactions, but the cross sections for these reactions are more than two orders of magnitude lower than that for ${ }^{147} \mathrm{Nd}(\mathrm{n}, \gamma){ }^{148} \mathrm{Nd}$ (Chadwick et al. 2011), so these would not explain the discrepancy. The most likely reason for the overestimation of the production of ${ }^{148} \mathrm{Nd}$ from ${ }^{147} \mathrm{Nd}(\mathrm{n}, \gamma)^{148} \mathrm{Nd}$ in the Table 3-7 values is that the ${ }^{147} \mathrm{Nd}$, with an 11-day half-life, would have decayed significantly during the reactor shutdowns that occurred throughout the AGR-2 irradiation test and that the impacts of reactor shutdowns were not accounted for in the continuous-irradiation calculation by Suyama and Mochizuki. This issue was identified in ORNL/TM-2018/931, and one of the reasons for the suggested application of a more rigorous correction method using the daily depletion simulation data.

Table 3-7. Correction factors used for ${ }^{147} \mathrm{Nd}(\mathrm{n}, \gamma)^{148} \mathrm{Nd}$ neutron capture reaction in ORNL/TM-2018/931

\begin{tabular}{lll}
\hline & AGR-2 Compact 2-2-2 & AGR-2 Compact 6-4-2 \\
\hline Fluence $\left(\mathrm{n} / \mathrm{m}^{2}\right)^{a}$ & $1.7 \mathrm{E} 26$ & $1.1 \mathrm{E} 26$ \\
Flux $\left(\mathrm{n} / \mathrm{m}^{2} \mathrm{~s}\right)^{b}$ & $3.5 \mathrm{E} 18$ & $2.3 \mathrm{E} 18$ \\
Correction factor for ${ }^{147} \mathrm{Nd}(\mathrm{n}, \gamma)^{148} \mathrm{Nd}^{c}$ & 0.971 & 0.981 \\
\hline
\end{tabular}

${ }^{a}$ Total neutron fluence estimated as $5 \times$ fast fluence from Table 1-1.

${ }^{b}$ Total neutron flux estimated by multiplying estimated total neutron fluence by 559.2 effective full power days (Collin 2014).

${ }^{c}$ Correction factor taken from Figure 3 of Suyama and Mochizuki (2005). 


\subsection{CALCULATION OF BURNUP}

Table 3-8 and Table 3-9 show the burnup values for ${ }^{143} \mathrm{Nd},{ }^{144} \mathrm{Nd},{ }^{145} \mathrm{Nd},{ }^{146} \mathrm{Nd},{ }^{148} \mathrm{Nd}$, and ${ }^{150} \mathrm{Nd}$ calculated three ways: (1) using the as-measured number of atoms, (2) using the number of atoms corrected for the generation and consumption of ${ }^{\mathrm{Z}} \mathrm{Nd}$ via the neutron capture reactions ${ }^{\mathrm{Z}-1} \mathrm{Nd}(\mathrm{n}, \gamma)^{\mathrm{Z}} \mathrm{Nd}$ and ${ }^{\mathrm{Z}} \mathrm{Nd}(\mathrm{n}, \gamma)^{\mathrm{Z}+1} \mathrm{Nd}$, and (3) using the number of atoms after applying an additional correction to account for contamination from natural $\mathrm{Nd}$ based on the ${ }^{142} \mathrm{Nd}$ measured in each sample and the natural abundance of the Nd isotopes, as described in ASTM E321-96 (2012) and ORNL/TM-2018/931 (Montgomery et al. 2018). The values that include only the $(\mathrm{n}, \gamma)$ reaction corrections are presented in bold font because they are the most reliable values from the analyses that have been performed in this study. The values that come from applying a correction based on the measured ${ }^{142} \mathrm{Nd}$ to subtract out natural contamination are provided for information only and should not be used because the underlying assumptions for this correction are not applicable to the AGR-2 fuel, as discussed subsequently.

Table 3-8 and Table 3-9 show that there was very good agreement between Sample A and Sample B for the Compact 3-3-1, Compact 3-3-2, and Compact 2-2-2 analyses. The analyses of the two samples of particles from Compact 6-4-2 deviated by about 5\%, which suggests an error was introduced at some stage of the analysis. As discussed in ORNL/TM-2018/931 (Montgomery et al. 2018), analysis of a third sample would aid in determining whether one of the measurements was biased. Comparison between the burnup values calculated using the various neodymium isotopes shows that the application of the (n, $\gamma)$ neutron capture reactions from Table 3-6 result in good convergence with the exception of the burnup determined from the measured ${ }^{144} \mathrm{Nd}$. Further analysis is needed to consider why the ${ }^{144} \mathrm{Nd}$ values are lower.

Table 3-8. Burnup based on fission production of ${ }^{\mathrm{Z}} \mathrm{Nd}$ in Compact 3-3-1 and Compact 3-3-2

\begin{tabular}{|c|c|c|c|c|c|}
\hline${ }^{\mathrm{Z}} \mathrm{Nd}$ & Correction & $\begin{array}{c}\text { AGR-2 Compact 3-3-1 } \\
\text { Sample A }\end{array}$ & $\begin{array}{c}\text { AGR-2 Compact 3-3-1 } \\
\text { Sample B }\end{array}$ & $\begin{array}{c}\text { AGR-2 Compact 3-3-2 } \\
\text { Sample A }\end{array}$ & $\begin{array}{c}\text { AGR-2 Compact 3-3-2 } \\
\text { Sample B }\end{array}$ \\
\hline \multirow[t]{3}{*}{${ }^{143} \mathrm{Nd}$} & none & $5.85 \% \pm 0.12 \%$ & $5.85 \% \pm 0.11 \%$ & $6.15 \% \pm 0.10 \%$ & $6.21 \% \pm 0.10 \%$ \\
\hline & $(\mathrm{n}, \gamma)$ only ${ }^{a}$ & $10.08 \% \pm 0.23 \%$ & $10.07 \% \pm 0.21 \%$ & $10.62 \% \pm 0.21 \%$ & $10.72 \% \pm 0.21 \%$ \\
\hline & $(\mathrm{n}, \gamma) \&{ }^{142} \mathrm{Nd}^{b}$ & $9.98 \% \pm 0.22 \%$ & $9.98 \% \pm 0.21 \%$ & $10.51 \% \pm 0.21 \%$ & $10.62 \% \pm 0.21 \%$ \\
\hline \multirow[t]{3}{*}{${ }^{144} \mathrm{Nd}$} & none & $14.60 \% \pm 0.29 \%$ & $14.58 \% \pm 0.27 \%$ & $15.08 \% \pm 0.25 \%$ & $14.99 \% \pm 0.25 \%$ \\
\hline & $(\mathrm{n}, \gamma)$ only ${ }^{a}$ & $9.46 \% \pm 0.21 \%$ & $9.45 \% \pm 0.20 \%$ & $9.77 \% \pm 0.19 \%$ & $9.71 \% \pm 0.19 \%$ \\
\hline & $(\mathrm{n}, \gamma) \&{ }^{142} \mathrm{Nd}^{b}$ & $9.25 \% \pm 0.21 \%$ & $9.24 \% \pm 0.20 \%$ & $9.54 \% \pm 0.19 \%$ & $9.48 \% \pm 0.19 \%$ \\
\hline \multirow[t]{3}{*}{${ }^{145} \mathrm{Nd}$} & none & $9.19 \% \pm 0.18 \%$ & $9.19 \% \pm 0.17 \%$ & $9.64 \% \pm 0.16 \%$ & $9.63 \% \pm 0.16 \%$ \\
\hline & $(\mathrm{n}, \gamma)$ only ${ }^{a}$ & $10.45 \% \pm 0.23 \%$ & $10.45 \% \pm 0.22 \%$ & $10.96 \% \pm 0.21 \%$ & $10.94 \% \pm 0.21 \%$ \\
\hline & $(\mathrm{n}, \gamma) \&{ }^{142} \mathrm{Nd}^{b}$ & $10.34 \% \pm 0.23 \%$ & $10.35 \% \pm 0.22 \%$ & $10.85 \% \pm 0.21 \%$ & $10.84 \% \pm 0.21 \%$ \\
\hline \multirow[t]{3}{*}{${ }^{146} \mathrm{Nd}$} & none & $11.82 \% \pm 0.23 \%$ & $11.80 \% \pm 0.22 \%$ & $12.26 \% \pm 0.20 \%$ & $12.27 \% \pm 0.20 \%$ \\
\hline & $(\mathrm{n}, \gamma)$ only ${ }^{a}$ & $10.44 \% \pm 0.23 \%$ & $10.41 \% \pm 0.22 \%$ & $10.82 \% \pm 0.21 \%$ & $10.83 \% \pm 0.21 \%$ \\
\hline & $(\mathrm{n}, \gamma) \&{ }^{142} \mathrm{Nd}^{b}$ & $10.17 \% \pm 0.23 \%$ & $10.15 \% \pm 0.22 \%$ & $10.53 \% \pm 0.21 \%$ & $10.54 \% \pm 0.21 \%$ \\
\hline \multirow[t]{3}{*}{${ }^{148} \mathrm{Nd}$} & none & $10.57 \% \pm 0.21 \%$ & $10.59 \% \pm 0.19 \%$ & $11.06 \% \pm 0.18 \%$ & $11.06 \% \pm 0.18 \%$ \\
\hline & $(\mathbf{n}, \gamma)$ only ${ }^{a}$ & $10.30 \% \pm 0.23 \%$ & $10.32 \% \pm 0.21 \%$ & $10.77 \% \pm 0.21 \%$ & $10.78 \% \pm 0.21 \%$ \\
\hline & $(\mathrm{n}, \gamma) \&{ }^{142} \mathrm{Nd}^{b}$ & $10.15 \% \pm 0.23 \%$ & $10.17 \% \pm 0.21 \%$ & $10.61 \% \pm 0.21 \%$ & $10.61 \% \pm 0.21 \%$ \\
\hline \multirow[t]{3}{*}{${ }^{150} \mathrm{Nd}$} & none & $10.22 \% \pm 0.20 \%$ & $10.21 \% \pm 0.18 \%$ & $10.65 \% \pm 0.17 \%$ & $10.59 \% \pm 0.17 \%$ \\
\hline & $(n, \gamma)$ only ${ }^{a}$ & $10.28 \% \pm 0.23 \%$ & $10.27 \% \pm 0.21 \%$ & $10.71 \% \pm 0.21 \%$ & $10.66 \% \pm 0.20 \%$ \\
\hline & $(\mathrm{n}, \gamma) \&{ }^{142} \mathrm{Nd}^{b}$ & $9.95 \% \pm 0.22 \%$ & $9.95 \% \pm 0.21 \%$ & $10.36 \% \pm 0.20 \%$ & $10.30 \% \pm 0.20 \%$ \\
\hline
\end{tabular}

Note: Values are in \%FIMA.

${ }^{a}$ Burnup values presented in bold font are recommended as the most reliable.

${ }^{b}$ Values listed in this table that include a natural contamination subtraction based on measured ${ }^{142} \mathrm{Nd}$ are for information only and should not be used because the underlying assumptions for this correction are not applicable to the AGR-2 fuel. 
Table 3-9. Burnup based on fission production of ${ }^{\mathrm{Z}} \mathrm{Nd}$ in Compact 2-2-2 and Compact 6-4-2

\begin{tabular}{|c|c|c|c|c|c|}
\hline${ }^{\mathrm{Z}} \mathrm{Nd}$ & Corrections & $\begin{array}{c}\text { AGR-2 Compact 2-2-2 } \\
\text { Sample A }\end{array}$ & $\begin{array}{c}\text { AGR-2 Compact 2-2-2 } \\
\text { Sample B }\end{array}$ & $\begin{array}{c}\text { AGR-2 Compact 6-4-2 } \\
\text { Sample A }\end{array}$ & $\begin{array}{c}\text { AGR-2 Compact 6-4-2 } \\
\text { Sample B }\end{array}$ \\
\hline \multirow[t]{3}{*}{${ }^{143} \mathrm{Nd}$} & none & $8.10 \% \pm 0.21 \%$ & $8.09 \% \pm 0.24 \%$ & $7.52 \% \pm 0.27 \%$ & $7.26 \% \pm 0.20 \%$ \\
\hline & $(n, \gamma)$ only ${ }^{a}$ & $12.74 \% \pm 0.36 \%$ & $12.72 \% \pm 0.40 \%$ & $9.76 \% \pm 0.36 \%$ & $9.43 \% \pm 0.28 \%$ \\
\hline & $(\mathrm{n}, \gamma) \&{ }^{142} \mathrm{Nd}^{b}$ & $12.64 \% \pm 0.36 \%$ & $12.63 \% \pm 0.40 \%$ & $9.72 \% \pm 0.36 \%$ & $9.39 \% \pm 0.28 \%$ \\
\hline \multirow[t]{3}{*}{${ }^{144} \mathrm{Nd}$} & none & $16.49 \% \pm 0.44 \%$ & $16.47 \% \pm 0.45 \%$ & $11.69 \% \pm 0.40 \%$ & $11.07 \% \pm 0.30 \%$ \\
\hline & $(\mathrm{n}, \gamma)$ only ${ }^{a}$ & $11.15 \% \pm 0.31 \%$ & $11.14 \% \pm 0.32 \%$ & $8.79 \% \pm 0.31 \%$ & $8.31 \% \pm 0.24 \%$ \\
\hline & $(\mathrm{n}, \gamma) \&{ }^{142} \mathrm{Nd}^{b}$ & $10.94 \% \pm 0.31 \%$ & $10.93 \% \pm 0.32 \%$ & $8.69 \% \pm 0.31 \%$ & $8.22 \% \pm 0.24 \%$ \\
\hline \multirow[t]{3}{*}{${ }^{145} \mathrm{Nd}$} & none & $11.47 \% \pm 0.22 \%$ & $11.39 \% \pm 0.31 \%$ & $9.34 \% \pm 0.30 \%$ & $8.90 \% \pm 0.22 \%$ \\
\hline & $(\mathrm{n}, \gamma)$ only ${ }^{a}$ & $12.78 \% \pm 0.27 \%$ & $12.69 \% \pm 0.37 \%$ & $9.96 \% \pm 0.34 \%$ & $9.50 \% \pm 0.25 \%$ \\
\hline & $(\mathrm{n}, \gamma) \&{ }^{142} \mathrm{Nd}^{b}$ & $12.68 \% \pm 0.27 \%$ & $12.59 \% \pm 0.37 \%$ & $9.92 \% \pm 0.34 \%$ & $9.45 \% \pm 0.25 \%$ \\
\hline \multirow[t]{3}{*}{${ }^{146} \mathrm{Nd}$} & none & $14.12 \% \pm 0.26 \%$ & $14.08 \% \pm 0.41 \%$ & $10.56 \% \pm 0.34 \%$ & $10.03 \% \pm 0.24 \%$ \\
\hline & $(\mathbf{n}, \gamma)$ only ${ }^{a}$ & $12.68 \% \pm 0.27 \%$ & $12.65 \% \pm 0.39 \%$ & $9.87 \% \pm 0.33 \%$ & $9.36 \% \pm 0.24 \%$ \\
\hline & $(\mathrm{n}, \gamma) \&{ }^{142} \mathrm{Nd}^{b}$ & $12.43 \% \pm 0.27 \%$ & $12.39 \% \pm 0.39 \%$ & $9.75 \% \pm 0.33 \%$ & $9.25 \% \pm 0.24 \%$ \\
\hline \multirow[t]{3}{*}{${ }^{148} \mathrm{Nd}$} & none & $12.96 \% \pm 0.28 \%$ & $13.03 \% \pm 0.51 \%$ & $10.06 \% \pm 0.34 \%$ & $9.59 \% \pm 0.22 \%$ \\
\hline & $(n, \gamma)$ only ${ }^{a}$ & $12.67 \% \pm 0.30 \%$ & $12.74 \% \pm 0.52 \%$ & $9.93 \% \pm 0.35 \%$ & $9.46 \% \pm 0.24 \%$ \\
\hline & $(\mathrm{n}, \gamma) \&{ }^{142} \mathrm{Nd}^{b}$ & $12.53 \% \pm 0.30 \%$ & $12.59 \% \pm 0.52 \%$ & $9.85 \% \pm 0.35 \%$ & $9.40 \% \pm 0.24 \%$ \\
\hline \multirow[t]{3}{*}{${ }^{150} \mathrm{Nd}$} & none & $12.44 \% \pm 0.23 \%$ & $12.66 \% \pm 0.65 \%$ & $9.79 \% \pm 0.31 \%$ & $9.34 \% \pm 0.22 \%$ \\
\hline & $(\mathrm{n}, \gamma)$ only ${ }^{a}$ & $12.50 \% \pm 0.27 \%$ & $12.72 \% \pm 0.67 \%$ & $9.82 \% \pm 0.33 \%$ & $9.37 \% \pm 0.24 \%$ \\
\hline & $(\mathrm{n}, \gamma) \&{ }^{142} \mathrm{Nd}^{b}$ & $12.16 \% \pm 0.27 \%$ & $12.39 \% \pm 0.67 \%$ & $9.66 \% \pm 0.33 \%$ & $9.21 \% \pm 0.24 \%$ \\
\hline
\end{tabular}

Note: Values are in \%FIMA.

${ }^{a}$ Burnup values presented in bold font are recommended as the most reliable.

${ }^{b}$ Values listed in this table that include a natural contamination subtraction based on measured ${ }^{142} \mathrm{Nd}$ are for information only and should not be used because the underlying assumptions for this correction are not applicable to the AGR-2 fuel.

The burnup values that include the correction for natural contamination in Table 3-8 and Table 3-9 are not recommended for use as a final result because the ASTM E321-96 (2012) assumption that the measured

${ }^{142} \mathrm{Nd}$ is representative of the natural contamination in the sample is not accurate for the AGR-2 compacts. Table 3-10 shows the amount of ${ }^{142} \mathrm{Nd}$ determined by the AGR-2 daily depletion calculation (Sterbentz 2014) compared with the average measured ${ }^{142} \mathrm{Nd}$ in the samples from each compact. The calculated amount of ${ }^{142} \mathrm{Nd}$ is from $63-74 \%$ of the measured value. Therefore, using the entire measured values for ${ }^{142} \mathrm{Nd}$ to subtract out possible contributions from natural contamination is not warranted for these compacts. Further work would be required to adjust for the amount of ${ }^{142} \mathrm{Nd}$ generated by irradiation before applying a correction for natural contamination based on the ${ }^{142} \mathrm{Nd}$ in the irradiated fuel.

Table 3-10. Average calculated moles of ${ }^{142} \mathrm{Nd}$ compared with measured moles of ${ }^{142} \mathrm{Nd}$

\begin{tabular}{lcccc}
\hline Value & AGR-2 Compact 3-3-1 & AGR-2 Compact 3-3-2 & AGR-2 Compact 2-2-2 & AGR-2 Compact 6-4-2 \\
\hline JMOCUP moles/compact & $3.60 \mathrm{E}-07$ & $3.65 \mathrm{E}-07$ & $4.92 \mathrm{E}-07$ & $2.18 \mathrm{E}-07$ \\
Particles/sample & 150 & 150 & 200 & 200 \\
Particles/compact & 1543 & 1543 & 3176 & 3176 \\
JMOCUP moles/sample ${ }^{a}$ & $3.50 \mathrm{E}-08$ & $3.55 \mathrm{E}-08$ & $3.10 \mathrm{E}-08$ & $1.37 \mathrm{E}-08$ \\
$\begin{array}{l}\text { Average measured } \\
\text { moles/sample }\end{array}$ & $5.38 \mathrm{E}-08$ & $5.61 \mathrm{E}-08$ & $4.40 \mathrm{E}-08$ & $1.871 \mathrm{E}-08$
\end{tabular}

${ }^{a}$ The JMOCUP value for the moles/sample was estimated from the JMOCUP moles/compact multiplied by the number of particles per sample and divided by the average number of particles per compact. 
As discussed in Section 3.2, the $(\mathrm{n}, \gamma)$ neutron capture reactions correction factors used in the analyses reported in ORNL/TM-2018/931 (Montgomery et al. 2018) for calculating burnup from the measured ${ }^{148} \mathrm{Nd}$ in the samples from Compact 2-2-2 and Compact 6-4-2 were based on an estimate of only the ${ }^{147} \mathrm{Nd}(\mathrm{n}, \gamma){ }^{148} \mathrm{Nd}$ neutron capture reaction. Table 3-11 shows that the different values given in Table 3-6 and Table 3-7 for the $(\mathrm{n}, \gamma)$ reaction correction factors only make a minor difference in the burnup value.

Table 3-11. Burnup from measured ${ }^{148} \mathrm{Nd}$ using different neutron capture reaction correction factors

\begin{tabular}{lcccc}
\hline Correction & $\begin{array}{c}\text { AGR-2 Compact 2-2-2 } \\
\text { Sample A }\end{array}$ & $\begin{array}{c}\text { AGR-2 Compact 2-2-2 } \\
\text { Sample B }\end{array}$ & $\begin{array}{c}\text { AGR-2 Compact 6-4-2 } \\
\text { Sample A }\end{array}$ & $\begin{array}{c}\text { AGR-2 Compact 6-4-2 } \\
\text { Sample B }\end{array}$ \\
\hline None & $12.96 \% \pm 0.28 \%$ & $13.03 \% \pm 0.51 \%$ & $10.06 \% \pm 0.34 \%$ & $9.59 \% \pm 0.22 \%$ \\
Table 3-6 (n, $\gamma)$ only & $12.67 \% \pm 0.30 \%$ & $12.74 \% \pm 0.52 \%$ & $9.93 \% \pm 0.35 \%$ & $9.46 \% \pm 0.24 \%$ \\
Table 3-7 (n, $\gamma)$ only & $12.63 \% \pm 0.30 \%$ & $12.70 \% \pm 0.52 \%$ & $9.89 \% \pm 0.35 \%$ & $9.43 \% \pm 0.24 \%$ \\
\hline
\end{tabular}

Note: Values are in \%FIMA. 


\section{CONCLUSIONS}

Burnup measurements have been completed on duplicate samples from AGR-2 $\mathrm{UO}_{2}$ Compact 3-3-1 and AGR-2 $\mathrm{UO}_{2}$ Compact 3-3-2. Burnup measurement results for AGR-2 UCO Compact 2-2-2 and AGR-2 UCO Compact 6-4-2 that were previously reported in ORNL/TM-2018/931 (Montgomery et al. 2018) were refined and expanded by applying additional calculations developed for the analysis of the Compact 3-3-1 and Compact 3-3-2 data. The burnup calculations in ASTM E321-96 (2012), on which the burnup calculations reported herein were based, use ${ }^{148} \mathrm{Nd}$ as a burnup indicator and recommend that corrections be made to subtract the contribution from natural neodymium in the as-fabricated fuel using the measured concentration of the ${ }^{142} \mathrm{Nd}$ shielded isotope and to account for additional ${ }^{148} \mathrm{Nd}$ production via the ${ }^{147} \mathrm{Nd}(\mathrm{n}, \gamma)^{148} \mathrm{Nd}$ neutron capture reaction. Comparison of the measured amount of ${ }^{142} \mathrm{Nd}$ with the amount of ${ }^{142} \mathrm{Nd}$ generated by the AGR-2 irradiation determined that the measured ${ }^{142} \mathrm{Nd}$ should not be used to correct for natural neodymium contribution in the compacts that were analyzed in this study and that the contribution from natural neodymium was probably insignificant compared with the uncertainty in the analysis. In contrast, the correction for the neutron capture reaction provided a moderate but important correction for accurate analysis of the burnup.

The online direct-injection isotope-dilution high-pressure-ion-chromatography inductively coupled plasma mass spectrometry technique that was used to analyze the burnup solutions provided reliable measurement of the stable and long-lived neodymium isotopes $\left({ }^{142} \mathrm{Nd},{ }^{143} \mathrm{Nd},{ }^{144} \mathrm{Nd},{ }^{145} \mathrm{Nd},{ }^{146} \mathrm{Nd},{ }^{148} \mathrm{Nd}\right.$, and ${ }^{150} \mathrm{Nd}$ ). Effective cumulative fission yields were available for all but the ${ }^{142} \mathrm{Nd}$ shielded isotope (Table 3-5). The availability of additional information from the AGR-2 daily depletion calculations (Sterbentz 2014) allowed the extraction of neutron capture reaction correction factors for all the relevant neodymium isotopes (Table 3-6). This allowed for burnup to be determined using multiple isotopes of neodymium (Table 3-8 and Table 3-9) rather than just ${ }^{148} \mathrm{Nd}$. Table 4-1 provides a summary of the results of the burnup analyses and a comparison of the results with the calculated burnup from the AGR-2 daily depletion calculations obtained using JMOCUP (Sterbentz 2014). The burnup values determined by averaging the individual burnup measurement using five of the neodymium isotopes $\left({ }^{143} \mathrm{Nd},{ }^{145} \mathrm{Nd},{ }^{146} \mathrm{Nd}\right.$, ${ }^{148} \mathrm{Nd}$, and ${ }^{150} \mathrm{Nd}$ ) were nearly identical to those obtained from ${ }^{148} \mathrm{Nd}$, but using all the available data from these five isotopes reduced the stochastic uncertainty in the analysis by more than a factor of two.

Comparison of the measured burnups with those calculated by Sterbentz (2014) showed reasonably good agreement. The largest difference was for Compact 6-4-2, which was at the top of the test train, where irradiation conditions were less uniform and not as well known.

Table 4-1. Summary of burnup analyses and comparison with JMOCUP calculations

\begin{tabular}{|c|c|c|c|c|c|c|c|c|}
\hline & Correction & Sam & le A & San & le B & Average & JMOCUP & Difference \\
\hline & Compact 3-3-1 & $10.30 \%$ & $=0.23 \%$ & $10.32 \%$ & $=0.21 \%$ & $10.31 \% \pm 0.16 \%$ & $10.46 \%$ & $-1.5 \%$ \\
\hline $148 \mathrm{~N}$ & Compact 3-3-2 & $10.77 \%$ & $=0.21 \%$ & $10.78 \%$ & $=0.21 \%$ & $10.77 \% \pm 0.15 \%$ & $10.54 \%$ & $2.2 \%$ \\
\hline & Compact 2-2-2 & $12.67 \%$ & $=0.30 \%$ & $12.74 \%$ & $=0.52 \%$ & $12.71 \% \pm 0.30 \%$ & $12.55 \%$ & $1.2 \%$ \\
\hline & Compact 6-4-2 & $9.93 \%$ & $=0.35 \%$ & $9.46 \%$ & $=0.24 \%$ & $9.69 \% \pm 0.21 \%$ & $9.26 \%$ & $4.5 \%$ \\
\hline & Compact 3-3-1 & $10.31 \%$ & $0.10 \%$ & $10.30 \%$ & $0.10 \%$ & $10.31 \% \pm 0.07 \%$ & $10.46 \%$ & $-1.5 \%$ \\
\hline All Nd & Compact 3-3-2 & $10.78 \%$ & $0.09 \%$ & $10.79 \%$ & $0.09 \%$ & $10.78 \% \pm 0.07 \%$ & $10.54 \%$ & $2.2 \%$ \\
\hline${ }^{144} \mathrm{Nd}$ & Compact 2-2-2 & $12.67 \%$ & $0.13 \%$ & $12.70 \%$ & $0.22 \%$ & $12.69 \% \pm 0.13 \%$ & $12.55 \%$ & $1.1 \%$ \\
\hline & Compact 6-4-2 & $9.87 \%$ & $0.15 \%$ & $9.42 \%$ & $0.11 \%$ & $9.65 \% \pm 0.09 \%$ & $9.26 \%$ & $4.0 \%$ \\
\hline
\end{tabular}

Note: Burnup values are in \%FIMA. 


\section{REFERENCES}

ASTM E321-96. 2012. Standard Test Method for Atom Percent Fission in Uranium and Plutonium Fuel (Neodymium-148 Method). West Conshohocken, PA: ASTM International.

Barnes, C. M., and D. W. Marshall. 2009. FY 2009 Particle Fabrication and Coater Test Report. INL/EXT-09-16545, Revision 0. Idaho Falls, ID: Idaho National Laboratory.

Chadwick, M. B., et al. 2011. "ENDF/B-VII.1 Nuclear Data for Science and Technology: Cross Sections, Covariances, Fission Product Yields and Decay Data." Nuclear Data Sheets 112, 2887-2996. Data downloaded from www.nndc.bnl.gov.

Collin, B. P. 2014. AGR-2 Irradiation Test Final As-Run Report. INL/EXT-14-32277, Revision 2. Idaho Falls, ID: Idaho National Laboratory.

Croff, A. G. 1983. "ORIGEN2: A Versatile Computer Code for Calculating the Nuclide Compositions and Characteristics of Nuclear Materials." Nucl. Tech. 62, 335-352.

Hawkes, G. L. 2014. AGR-2 Daily As-Run Thermal Analyses. INL/ECAR-2476, Revision 1. Idaho Falls, ID: Idaho National Laboratory.

Hunn, J. D., F. C. Montgomery, and P. J. Pappano. 2010a. Data Compilation for AGR-2 UCO Variant Compact Lot LEU09-OP2-Z. ORNL/TM-2010/017, Revision 1. Oak Ridge, TN: Oak Ridge National Laboratory.

Hunn, J. D., F. C. Montgomery, and P. J. Pappano. 2010b. Data Compilation for AGR-2 $\mathrm{UO}_{2}$ Compact Lot LEU11-OP2-Z. ORNL/TM-2010/055, Revision 1. Oak Ridge, TN: Oak Ridge National Laboratory.

Hunn, J. D., R. N. Morris, C. A. Baldwin, F. C. Montgomery, C. M. Silva, and T. J. Gerczak. 2013. AGR1 Irradiated Compact 4-4-2 PIE Report. ORNL/TM-2013/236, Revision 0. Oak Ridge, TN: Oak Ridge National Laboratory.

Ludwig, S. B., and A. G. Croff. 2002. ORIGEN2.2-Isotope Generation and Depletion Code Matrix Exponential Method. Oak Ridge, TN: Oak Ridge National Laboratory.

Montgomery, F. C., J. D. Hunn, T. J. Keever, B. D. Roach, R. H. Ilgner, E. K. Fenske, and J. M. Giaquinto. 2018. Measurement of Average Burnup in TRISO-Coated Particles from AGR-2 UCO Compacts 2-2-2 and 6-4-2. ORNL/TM-2018/931, Revision 0. Oak Ridge, TN: Oak Ridge National Laboratory.

Morris, R. N., C. A. Baldwin, J. D. Hunn, and P. A. Demkowicz. 2016. "Initial Results from Safety Testing of US AGR-2 Irradiation Test Fuel," Paper HTR2016-18574. Proc. 8th International Topical Meeting on High Temperature Reactor Technology (HTR-2016), Las Vegas, Nevada, November 610, 2016. Also published in Nucl. Eng. Des. 329, 124-133.

Sterbentz, J. W. 2014. JMOCUP As-Run Daily Depletion Calculation for the AGR-2 Experiment in the ATR B-12 Position. ECAR-2066, Revision 2. Idaho Falls, ID: Idaho National Laboratory.

Suyama, K., and H. Mochizuki. 2005. "Effect of Neutron Induced Reactions of Neodymium-147 and 148 on Burnup Evaluation.” J. Nucl. Science and Technology 42(7): 661-669.

X-5 Monte Carlo Team. 2003. MCNP_A General Monte Carlo N-Particle Transport Code. Version 5, Volume I (LA-UR-03-1987) and Volume II (LA-CP-03-0245). Los Alamos, NM: Los Alamos National Laboratory. 